\section{Isoniazid Preventative Therapy uptake for child household contacts of tuberculosis index cases, Kisumu County, Kenya, 2014-2015}

\author{
Barbara Burmen, ${ }^{1,2}$ Kennedy Mutai, ${ }^{1}$ \\ Timothy Malika ${ }^{3}$ \\ ${ }^{1}$ Kenya Medical Research \\ Institute/Center for Global Health \\ Research, Kisumu; ${ }^{2}$ Maseno University, \\ Maseno; ${ }^{3}$ National Tuberculosis, \\ Leprosy and Lung Diseases Program, \\ Kisumu County, Kenya
}

\section{Abstract \\ Isoniazid Preventative Therapy (IPT) is} recommended for children aged less than 5 years that have been in contact with an open case of $\mathrm{TB}$, and screen negative for $\mathrm{TB}$, to prevent the risk of TB progression. We examined IPT uptake among child household contacts of TB index cases, within a TB case detection study, in a high TB burden region. A cross-sectional study involving all IPT-eligible children drawn from a TB case detection study was done in Kisumu County, Kenya between 2014 and 2015. By linking a subset of the study database to the TB program IPT register, we described Child contacts as initiated on IPT and TB index cases as having child contacts initiated on IPT based on whether their names or their child contacts names respectively, were found in the IPT register. Logistic regression analysis was used to describe index and contact characteristics associated with IPT initiation. Of 555 TB index cases recruited into the study, $243(44 \%)$ had a total of 337 IPT-eligible child contacts. Forty-seven (19\%) index cases that had child contacts initiated on IPT; they were more likely to have been diagnosed with smear positive TB compared to those who were diagnosed with smear negative $\mathrm{TB}$ (OR 5.1, 95\%CI 1.1-23.2; $\mathrm{P}=0.03$ ) and to reside in rural Kisumu compared to those in urban Kisumu (OR 3.3, 95\% CI 1.6-6.8; $\mathrm{P}<0.01)$. The $51(15 \%)$ child contacts that were initiated on IPT were more likely to be were first degree relatives of the index case compared to those who were not (OR 2.6, $95 \%$ CI 1.2-5.5; $\mathrm{P}=0.02$ ) and to reside in rural Kisumu compared to those in urban Kisumu (OR 2.6, 95\% CI 1.2-5.1; $\mathrm{P}<0.01$ ). IPT initiation, which is influenced by index and contact characteristics, is suboptimal. The TB program should provide health worker training, avail appropriate pediatric
TB diagnostic tools, job aids and monitoring tools, and ensure continuous supply of medication, and to facilitate IPT implementation. Additionally, targeted health education interventions should be formulated to reach those who are unlikely to accept IPT.

\section{Introduction}

Tuberculosis is highly infectious; a person with active TB can infect up to 15 persons a year through close contact. ${ }^{1}$ A person acquires TB infection via inhalation or ingestion. ${ }^{1}$ In $90 \%$ of infections, the primary infection is self-limiting and eliminated by the hosts' immune mechanism. In 5-15\% of infections, viable bacteria may either spread to the blood stream leading to TB lesions in multiple organs, or be suppressed into an inactive form called Latent tuberculosis infection (LTBI). ${ }^{2}$ Persons with LTBI (also called asymptomatic infection) cannot spread TB; however, if left untreated, 5$10 \%$ of persons with LTBI will develop disease and contribute to infectious TB cases. ${ }^{3,4}$ Persons with asymptomatic infection are at risk of reactivating their infection; for this reason they are screened using chest $\mathrm{X}$ ray to determine whether they should receive chemotherapy or chemoprophylaxis. $^{2,4}$

Chemoprophylaxis with Isoniazid is given to persons with LTBI identified during contact tracing to prevent disease progression, and to patients with healed scars of TB to prevent recrudescence of TB. ${ }^{4,5}$ It achieves an efficacy of $90-93 \%$ on full completion. ${ }^{3}$

Among adults, 88 contacts should be treated to prevent one case; however, among children aged $0-4$ years, only 6 contacts should be treated to prevent a case of TB. This justifies the use of chemoprophylaxis in children aged less than 5 years. ${ }^{3}$ Based on the WHO guidelines, the TB program in Kenya therefore recommends IPT administration for children aged less than 5 years, who have been exposed to an open case of TB, and screen negative for TB. ${ }^{6}$

The prevention of TB among contacts of TB source cases depends on their willingness to accept and adhere to a chemoprophylaxis regimen. Nevertheless, even with sub-optimal completion rates, chemoprophylaxis affords an absolute risk reduction rate of $1.1 \%{ }^{3}$ In Kenya, of 28 smear positive cases reported in one quarter in 2012 at the Jaramogi Oginga Odinga Teaching and referral hospital, the largest regional public health facility in the former Nyanza province, only 18 children had been screened for $\mathrm{TB}$ and 5 received IPT (Program Coordinator, Clinical Services,
Correspondence: Barbara Burmen, Kenya Medical Research Institute/Center for Global Health Research, P.o. Box 1578-40100, Kisumu, Kenya.

Tel./Fax: +254722983432

E-mail: bburmen@kemricdc.org

Key words: pediatric, Tuberculosis, Household contact, TB chemoprophylaxis.

Acknowledgments: the authors would acknowledge the contribution of TB patients, the Division of Leprosy, Tuberculosis and Lung diseases in Kenya, Maseno University, the Centers for Disease Control and Prevention Division of Global HIV/AIDS and Tuberculosis, and the Director of the Kenya Medical Research Institute to this success of this publication.

Contributions: BB participated in data collection, analysis and manuscript writing. KM participated in study design, data collection, data analysis and manuscript development. TM provided study oversight and manuscript review.

Conflict of interest: the authors declare no potential conflict of interest.

Funding: This publication was made possible by support from the U.S. President's Emergency Plan for AIDS Relief (PEPFAR) through cooperative agreement No.5U19GH000041] from the U.S. Centers for Disease Control and Prevention (CDC), Division of Global HIV/AIDS (DGHA).

Conference presentation: parts of this work has been shared at the Union African Regional Conference, Accra Ghana, July 2017 and The World Academy of Sciences Regional Office for South and Central Asia (TWAS ROCASA) Young Scientists Conference, Infectious Diseases-From Biology to Intervention, Bangalore, India, 7-9th September 2017

Received for publication: 2 December 2017 Accepted for publication: 19 February 2018.

This work is licensed under a Creative Commons Attribution NonCommercial 4.0 License (CC BY-NC 4.0).

CCopyright B. Burmen et al., 2019

Licensee PAGEPress, Italy

Journal of Public Health in Africa 2019; 10:827 doi:10.4081/jphia.2019.827

HIV Implementation Science and Services Branch, Kenya Medical Research Institute, Personal Communication, 30 ${ }^{\text {th }}$ June, 2012). In India - where contact screening for all child contacts aged $<14$ years and Isoniazid Prophylactic Treatment administration for childhood household contacts aged less 
than 6 years is recommended by the national TB program - only $14 \%$ of contacts aged less than 14 years were screened for TB and only $19 \%$ of contacts aged less than 6 years had been initiated on IPT. There was no documentation of completion rates. ${ }^{7}$ Only $27 \%$ of contacts who met criteria for referral for IPT in Australia in 1991 were referred for chemoprophylaxis and once referred, fewer actually got treated. ${ }^{8}$

This paper examined the uptake of IPT among children who were identified as household contacts of index cases of patients with TB within a TB case detection study in Kisumu County, Western Kenya.

\section{Materials and Methods}

\section{Study design and setting}

A retrospective cross-sectional study of all IPT-eligible children, based on the TB Control guidelines in Kenya, was done in Kisumu County, Kenya between 2014 and $2015 .^{6}$

Kisumu County located in Western Kenya, has a population of 1,097,307 of whom $17.4 \%$ are aged less than 5 years. ${ }^{9}$ The county has 109 drug-susceptible TB treatment sites, 75 drug-resistant TB treatment sites and $80 \mathrm{~TB}$ diagnostic sites. ${ }^{10} \mathrm{In}$ 2015, the TB incidence was 105 per 100,000 and the TB prevalence was 306 per $100,000 .{ }^{10}$ The TB contact investigation study identified all household members aged less than 5 years who had been in contact with an index case of drug- susceptible $\mathrm{TB}$, currently registered at TB clinics within Kisumu County. All household contacts all underwent $\mathrm{TB}$ screening after which they were referred to the TB clinics for further management. No treatment was provided within the study.

\section{Study population}

All children aged less than 5 years drawn from the TB contact investigation study, who had been in household contact with a Tuberculosis index case and were not diagnosed with TB, whose parents or guardians consented to their participation in the study, were eligible for inclusion.

\section{Clinical care}

As per the Kenyan TB program guidelines, all children aged less than 5 years (child contacts) who have been in household contact with an index case of TB and have not been diagnosed with TB, should be given TB prophylaxis using Isoniazid Preventative Therapy (IPT) for a period of 6 months. During the period of IPT administration, persons on IPT should be routinely screened for TB symptoms in the event there is a need to stop IPT and commence TB treatment. Additionally, they should be reviewed for adverse events at each visit. ${ }^{6}$

\section{Procedures \\ Preparation of study databases}

Demographic and clinical information of children aged less than 5 years who were not diagnosed with TB were abstracted from the TB Contact Investigation study's electronic databases (Database 1).

As the details of IPT initiation and completion were not documented by the study; we reviewed IPT registers from the TB program to find out whether study participants had received IPT. Clinical and demographic details of all persons who had been initiated on IPT in Kisumu County in 2014 and 2015 were obtained from the county's TB program databases (Database 2). Database 2 included identification details, dates of IPT initiation, whether or not the participant completed IPT and dates of Completion of IPT. Reasons for non-initiation and noncompletion of IPT were not documented in the IPT program registers.

\section{Manual linkage of participant information}

The two databases were linked using participant identification details, ages, dates of enrolment into study, dates of determination of IPT eligibility and dates entered into the TB program registers to form a new database (Database 3). Because the index case and his or her household contact were not obliged to attend the same clinic, the clinic names were not always used in the linking process.

\section{Data analysis}

A descriptive analysis was used to summarize socio demographic characteristics of TB index cases and their contacts. Child contacts were described as having been initiated on IPT if their names were documented in the IPT register. TB index cases were described as having their child contacts initiated on IPT in the names of the child contacts were found in the IPT register. Logistic regression analysis was used to describe index, and contact characteristics associated with IPT initiation. A cut off of $\mathrm{P}<0.20$ in univariate analysis was used to determine variables to include in the multivariate model. Using backward elimination, a final model was developed by retaining variables that had a $\mathrm{P}<0.05 .{ }^{11}$ Analysis was done using SAS 9.2.12

\section{Ethical considerations}

Ethical approval to conduct this study was granted by the Kenya Medical Research Institute Ethics Committee (SSC 2408).

\section{Results}

\section{Identification of child household contacts of TB index cases}

A total of 2396 TB index cases were diagnosed in Kisumu County in 2014 and $2015 ;{ }^{10}$ of these $19 \%$ (555) were recruited into the study. The majority $(n=445 ; 80 \%)$ had at least one household contact and approximately half of them $(n=243 ; 55 \%)$ had at least one household contact aged less than 5 years.

The 243 TB index cases had a total of 345 household contacts aged less than 5 years in this ratio: 161 had one child contact each, 65 had two child contacts each, 14 had three child contacts each and 3 had four child contacts each. Eight of the child contacts linked to $8 \mathrm{~TB}$ indexes were diagnosed with TB; there were 2 child contacts with TB among index cases that had one child contact each, 2 child contact with TB among index cases that had two child contacts each, 3 child contacts with TB among index cases that had three child contacts each, and 1 child contact with TB among index cases that had four child contacts each.

The 337 who were not diagnosed with TB were therefore eligible for IPT initiation. ${ }^{6}$ The contacts that were eligible for IPT initiation were 159 among index cases that had one child contact each, 128 among index cases that had two child contact each, 39 among index cases that had three child contact each, and 11 among index cases that had four child contact each. Only two of 8 TB index cases that had a child contact diagnosed with TB had only one child contact living with them, the other 6 had more than one child contact household contact living with them that were not diagnosed with TB and were therefore eligible for IPT initiation. This therefore means 241 TB index cases had IPT-eligible child household contacts (Table 1). The ratio of the total number of TB index cases recruited into the study to number of child contacts aged less than 5 years was 1:0.62.

\section{Characteristics of TB index cases}

Majority were aged $15-45$ years $(80 \%)$, male (53\%), from urban Kisumu (69\%), non-smokers $(89 \%)$, had one child household contact $(68 \%)$, presented with cough (81\%), had pulmonary TB (93\%), which was smear positive $(84 \%)$, with abnormal chest $\mathrm{X}$ rays $(87 \%)$ and were HIV positive (52\%) (Table 1). The mean age of all TB index cases was $(n=554)$ was $32.7( \pm 13.9)$ years and the mean age of TB index cases with child contacts $(n=243)$ was 30.9 $( \pm 13.1)$ years (Data not shown). 
TB index Factors predictive of IPT initiation among child household contacts after household exposure to an index case of TB, Kisumu, County, 2014-2015

Forty-seven (19\%) of the TB index cases had their child contacts initiated on IPT. This included 3 index cases that had two household contacts each that had both child contacts initiated on IPT, and 1 index case who had three IPT-eligible child household contacts but only two initiated on IPT (Table 2). Index cases that had their child contacts initiated on IPT were more likely to reside in rural Kisumu compared to those in urban Kisumu (OR 3.3, 05\% CI $1.6-6.8 ; \mathrm{P}<0.01)$ and to have been diagno- sed with smear positive TB compared to those who were diagnosed with smear negative TB (OR 5.1, 95\% CI 1.1-23.2; $\mathrm{P}=0.03$ ) (Table 3). There was a higher proportion of contacts initiated on IPT where the index cases had more than one child contact compared to when the index had only one child contact; but this was not statistically significant (Table 3).

Table 1. Tuberculosis (TB) diagnosis, Isoniazid Preventative Therapy (IPT) eligibility and IPT initiation among child household contacts of TB index cases in Kisumu County, 2014-2015.

\begin{tabular}{|c|c|c|c|c|c|}
\hline Child contacts/ index case & \#1 & \#2 & \#3 & \#4 & Total \\
\hline Index cases & 161 & 65 & 14 & 3 & 243 \\
\hline Child contacts & 161 & 130 & 42 & 12 & 345 \\
\hline Child contacts diagnosed with TB & 2 & 2 & 3 & 1 & 8 \\
\hline Index cases with child contacts with TB & 159 & 128 & 39 & 11 & 337 \\
\hline Child contacts not diagnosed with TB & 24 & 21 & 5 & 1 & 51 \\
\hline Index cases with at least one child contacts not diagnosed with TB & 2 & 2 & 3 & 1 & 8 \\
\hline Child contacts not diagnosed with TB initiated on IPT & 159 & 65 & 14 & 3 & 241 \\
\hline Index cases with at least one child contacts not diagnosed with TB and started on IPT & 24 & 18 & 4 & 1 & 41 \\
\hline
\end{tabular}

Table 2. Characteristics of Index cases of tuberculosis (TB) at Kisumu County, with Isoniazid Preventative Therapy (IPT)-eligible household contacts aged less than 5 years by IPT initiation status, 2014-2015.

\begin{tabular}{|c|c|c|c|}
\hline Characteristics & $\begin{array}{l}\text { Total (241) } \\
\text { N. }(\%)\end{array}$ & $\begin{array}{l}\text { Child contact initiated on IPT } 47(20 \%) \text {; } \\
\text { N. ( } \%)\end{array}$ & $\begin{array}{l}\text { Child contact initiated on IPT } 191(80 \%) \text {; } \\
\text { N. (\%) }\end{array}$ \\
\hline \multicolumn{4}{|l|}{ Age group } \\
\hline $\begin{array}{l}<15 \text { year } \\
15-29 \text { years } \\
30-45 \text { years } \\
45+\text { years }\end{array}$ & $\begin{array}{l}18(8) \\
101(42) \\
92(38) \\
30(12)\end{array}$ & $\begin{array}{l}3(17) \\
24(24) \\
16(18) \\
4(14)\end{array}$ & $\begin{array}{l}15(83) \\
77(76) \\
76(82) \\
26(86)\end{array}$ \\
\hline $\begin{array}{l}\text { Sex } \\
\quad \text { Male } \\
\text { Female }\end{array}$ & $\begin{array}{l}129(53) \\
112(47)\end{array}$ & $\begin{array}{l}27(21) \\
20(18)\end{array}$ & $\begin{array}{c}102(79) \\
92(82)\end{array}$ \\
\hline $\begin{array}{l}\text { Region } \\
\text { Kisumu Urban } \\
\text { Kisumu rural }\end{array}$ & $\begin{array}{l}167(69) \\
74(31)\end{array}$ & $\begin{array}{l}26(16) \\
21(28)\end{array}$ & $\begin{array}{l}139(84) \\
52(72)\end{array}$ \\
\hline $\begin{array}{l}\text { Smoked in the past } 6 \text { mor } \\
\text { Yes } \\
\text { No }\end{array}$ & $\begin{array}{c}27(11) \\
214(89)\end{array}$ & $\begin{array}{c}3(11) \\
44(21)\end{array}$ & $\begin{array}{c}24(89) \\
170(79)\end{array}$ \\
\hline $\begin{array}{l}\text { Number of household cor } \\
\quad 1 \\
2 \\
3 \\
4\end{array}$ & $\begin{array}{l}159(68) \\
65(27) \\
14(4) \\
3(1)\end{array}$ & $\begin{array}{l}24(15) \\
18(28) \\
4(29) \\
1(33)\end{array}$ & $\begin{array}{l}135(85) \\
47(72) \\
10(71) \\
2(67)\end{array}$ \\
\hline $\begin{array}{l}\text { Cough } \\
\text { Present } \\
\text { Absent }\end{array}$ & $\begin{array}{c}196(81) \\
45(19)\end{array}$ & $\begin{array}{l}39(20) \\
8(18)\end{array}$ & $\begin{array}{l}157(80) \\
37(82)\end{array}$ \\
\hline $\begin{array}{l}\text { TB type* } \\
\text { Pulmonary } \\
\text { Extrapulmonary }\end{array}$ & $\begin{array}{c}224(93) \\
16(7)\end{array}$ & $\begin{array}{c}47(21) \\
0(0)\end{array}$ & $\begin{array}{l}177(79) \\
16(100)\end{array}$ \\
\hline $\begin{array}{l}\text { Smear Grade** } \\
\text { Positive } \\
\text { Negative }\end{array}$ & $\begin{array}{l}179(84) \\
33(16)\end{array}$ & $\begin{array}{l}38(21) \\
2(6)\end{array}$ & $\begin{array}{l}141(79) \\
31(94)\end{array}$ \\
\hline $\begin{array}{l}\text { Chest } \mathrm{X} \text { ray results*** } \\
\text { Normal } \\
\text { Abnormal cavitary } \\
\text { Abnormal non cavitary }\end{array}$ & $\begin{array}{l}22(13) \\
69(40) \\
78(47)\end{array}$ & $\begin{array}{l}4(18) \\
17(25) \\
12(15)\end{array}$ & $\begin{array}{l}18(72) \\
52(75) \\
66(85)\end{array}$ \\
\hline $\begin{array}{l}\text { HIV status } \\
\text { Positive } \\
\text { Negative }\end{array}$ & $\begin{array}{l}126(52) \\
115(48)\end{array}$ & $\begin{array}{l}23(18) \\
24(21)\end{array}$ & $\begin{array}{c}103(82) \\
91(79)\end{array}$ \\
\hline
\end{tabular}

*Missing information on Tb type for 1 participants; **missing information on sputum Smear results for 29 participants; ${ }^{* * *}$ missing chest X ray results for 72 participants . 


\section{Characteristics of IPT-eligible child household contacts}

Majority were aged $<4$ years $(80 \%)$, male $(52 \%)$, from urban Kisumu (68\%), were first degree relatives of the index case (66\%), had shared living quarters with the TB index case for 90 days or more (68\%) during which they had a daily contact of at least 8 hours duration $(69 \%)$, had shared a bedroom with the index case $(61 \%)$, had received BCG vaccination and a scar was visible at the time of interview $(90 \%)$, had never received TB prophylaxis $(95 \%)$ or treatment in the past $(99 \%)$, were HIV negative (96\%) and were asymptomatic (73\%) (Table 4). Data not shown indicates that among the 51 Contacts, who were initiated on IPT, 38 were children (20 daughters and 18 sons) to the index cases, 6 were nieces, 3 were siblings, 3 were grandchildren and 1 was a friend.

\section{Child household contact characteris-} tics predictive of IPT initiation after household exposure to an index case of Tb, Kisumu, County, 214-2015

Fifty-one (15\%) of 337 IPT eligible children were initiated on IPT. Children who initiated on IPT were more likely to be first degree relatives of the index case compared to those who were not (OR 2.6, 95\% CI 1.2-5.5; $\mathrm{P}=0.02$ ) and from the rural Kisumu region compared to urban Kisumu (OR 2.6, 95\% CI 1.2-5.1; $\mathrm{P}<0.01$ ) (Table 5).

There was a higher proportion of contacts initiated on IPT where the contact was female, had received BCG vaccine but there was no scar present, and had ever received IPT in the past. However, this did not achieve statistical significance. None of the contacts who had TB in the past was initiated on IPT (Table 4).

\section{Discussion}

Our evaluation illustrated a TB index case to child contact ratio of 1:0.62. This ratio was lower than that recommended by the WHO and Kenyan TB treatment guidelines of at least one child contact aged less than 5 years initiated on IPT, for every TB index case diagnosed (1:1). ${ }^{13}$ This ratio however, has to take into consideration the mean age of TB index cases. In India, where the mean age of sputum smear positive patients was 46 years, the majority did not have a child contact aged less than 6 years. ${ }^{14}$ However, in our study the mean age of all TB patients (including those with child contacts) was approximately 15 years younger. Nevertheless, this ratio may have also been higher if we were able to recruit more TB index cases and their household contacts, including those who declined to participate or were untraceable.

We found an IPT initiation rate of $15 \%$ among IPT-eligible children in this study. In the literature, IPT initiation rates in Africa range from $18 \%$ to $68 \%$. ${ }^{15}$ The 2006 recommendations of the Wolfheze conferences for contact investigation state that at least $85 \%$ of contacts with LTBI should be put on treatment with a minimum of three-fourths of them completing treatment. ${ }^{1}$ This evaluation therefore illustrated that IPT uptake and completion rates were suboptimal. It is difficult to infer why IPT our IPT initiation rates were low since the reasons for non-initiation were not documented. In the literature, this variation has been attributed to low

Table 3. Multivariate logistic regression illustrating characteristics of Index cases of tuberculosis (TB) at Kisumu County, with Isoniazid Preventative Therapy (IPT)-eligible household contacts aged less than 5 years, 2014-2015, by IPT initiation status.

\begin{tabular}{|c|c|c|c|c|c|}
\hline Characteristics & $\begin{array}{c}\text { IPT initiation//Total 47/238 (20\%); } \\
\text { N. (\%) }\end{array}$ & $\begin{array}{l}\text { Crude Odds Ratio } \\
\text { (95\% CI) }\end{array}$ & P value & $\begin{array}{l}\text { Adjusted Odds Ratio } \\
\text { (95\% CI) }\end{array}$ & P value \\
\hline $\begin{array}{l}\text { Age group } \\
\quad<15 \text { year } \\
15-29 \text { years } \\
\text { 30-45 years } \\
45+\text { years }\end{array}$ & $\begin{array}{c}3 / 18(17) \\
24 / 101(24) \\
16 / 92(18) \\
4 / 30(14)\end{array}$ & $\begin{array}{l}\text { Ref } \\
1.6(0.4-5.8) \\
1.1(0.3-4.1) \\
0.8(0.2-3.9)\end{array}$ & 0.5 & & \\
\hline $\begin{array}{l}\text { Sex } \\
\quad \text { Male } \\
\quad \text { Female }\end{array}$ & $\begin{array}{l}27 / 129(21) \\
20 / 112(18)\end{array}$ & $\begin{array}{l}1.2(0.6-2.3) \\
\quad \text { Ref }\end{array}$ & 0.5 & & \\
\hline $\begin{array}{l}\text { Region } \\
\text { Kisumu Urban } \\
\text { Kisumu rural }\end{array}$ & $\begin{array}{l}26 / 167(16) \\
21 / 74(28)\end{array}$ & $\begin{array}{c}\text { Ref } \\
2.2(1.1-4.2)\end{array}$ & $0.02^{*}$ & $\begin{array}{c}\text { Ref } \\
3.3(1.6-6.8)\end{array}$ & $<0.01$ \\
\hline $\begin{array}{l}\text { Smoked in the past } 6 \text { mont } \\
\text { Yes } \\
\text { No }\end{array}$ & $\begin{array}{c}3 / 27(11) \\
44 / 214(21)\end{array}$ & $\begin{array}{l}0.5(0.1-1.7) \\
\quad \text { Ref }\end{array}$ & 0.3 & & \\
\hline $\begin{array}{l}\text { No. of household contacts } \\
1 \\
2+\end{array}$ & ts aged $<5$ & $\begin{array}{c}\text { Ref } \\
2.3(1.2-4.4)\end{array}$ & $0.01^{*}$ & $\begin{array}{c}\text { Ref } \\
1.9(0.9-4.1)\end{array}$ & 0.06 \\
\hline $\begin{array}{l}\text { Cough } \\
\text { Present } \\
\text { Absent } \\
\end{array}$ & $\begin{array}{l}39 / 196(21) \\
8 / 45(18)\end{array}$ & $\begin{array}{l}1.2(0.5-2.7) \\
\text { Ref }\end{array}$ & 0.7 & & \\
\hline $\begin{array}{l}\text { Smear Grade** } \\
\text { Positive } \\
\text { Negative }\end{array}$ & $\begin{array}{l}38 / 179(21) \\
2 / 33(6)\end{array}$ & $\begin{array}{l}4.3(0.9-18.6) \\
\quad \text { Ref }\end{array}$ & $0.03^{*}$ & $\begin{array}{l}5.1(1.1-23.2) \\
\quad \text { Ref }\end{array}$ & 0.03 \\
\hline $\begin{array}{l}\text { Chest } X \text { ray results*** } \\
\text { Normal } \\
\text { Abnormal cavitary } \\
\text { Abnormal non cavitary }\end{array}$ & $\begin{array}{l}4 / 22(18) \\
17 / 69(25) \\
12 / 78(15)\end{array}$ & $\begin{array}{c}\text { Ref } \\
1.5(0.4-4.9) \\
0.8(0.2-2.8)\end{array}$ & 0.3 & & \\
\hline $\begin{array}{l}\text { HIV status } \\
\text { Positive } \\
\text { Negative } \\
\end{array}$ & $\begin{array}{l}23 / 126(18) \\
24 / 115(21)\end{array}$ & $\begin{array}{l}0.8(0.4-1.6) \\
\quad \operatorname{Ref} \\
\end{array}$ & 0.6 & & \\
\hline
\end{tabular}

*Entered into the multivariate logistic model; **missing information on sputum Smear results for 29 participants; ***missing chest X ray results for 72 participants; TB type excluded due to no participants with extrapulmonary TB being initiated on IPT. 
awareness by health workers, challenges in excluding a TB diagnosis, providers fear of toxicity, long duration of treatment and lack of parental knowledge on benefits of IPT. ${ }^{15}$ These reasons may partly explain why the three contacts who had been treated for TB prior to the onset of the study were not put on IPT. Although this did not achieve statistical significance, there were more children who were initiated on IPT among those who had previously received TB preventative therapy. It is possible that their parents /guardians were well informed about the benefits of IPT prior to the second round of IPT initiation. In the literature, inadequate information provided by health workers has been cited as a reason for low IPT initiation rates. ${ }^{16}$ Our evaluation also illustrated that children who were reported to have recei- ved BCG vaccine but did not have a scar were more likely to be put on IPT. It is possible that the clinicians felt that these children may have impaired immunity to TB. It was also possible that some children who received IPT may have not been documented since the program was in its inception (Kisumu County TB and Leprosy Coordinator, $15^{\text {th }}$ June 2017; Personal communication); the IPT initiation rates at the different localities may have varied from that we found or have been higher should all the children have been documented.

IPT initiation was higher among child household contacts that resided in rural areas. TB clinics in rural facilities have a lower patient workload than those in urban health facilities. A high patient to health worker ratio has been shown to compromise quality of care, ${ }^{17}$ as indicated by the proportion of patients who receive a recommended service i.e. IPT eligible patients initiated on IPT in our evaluation. ${ }^{18}$

TB index cases that may have perceived themselves to be sicker, as evidenced by smear positive pulmonary $\mathrm{TB}$, were also more likely to have their child household contacts initiated on IPT. Such persons may have felt that their children were at an increased risk of contracting TB from them. ${ }^{1}$ IPT was more likely to be initiated where the contact was closely related to the index case and commonly a parent to the child contact. Index cases, who were minors (aged less than 15 years) or not a close relation to the child contact, may have not been in a position to make treatment decisions about child household contacts. In the lite-

Table 4. Characteristics Isoniazid Preventative Therapy (IPT)-eligible household contacts (aged less than 5 years) of Index cases of tuberculosis (TB) at Kisumu County by IPT initiation status, 2014-2015.

\begin{tabular}{|c|c|c|c|}
\hline Characteristics & $\begin{array}{c}\text { Total (337); } \\
\text { N. (\%) }\end{array}$ & $\begin{array}{c}\text { Initiated on IPT } 51(15 \%) \text {; } \\
\text { N. (\%) }\end{array}$ & $\begin{array}{c}\text { Not Initiated on IPT } 286(85 \%) \text {; } \\
\text { N. (\%) }\end{array}$ \\
\hline $\begin{array}{l}\text { Age group } \\
\quad<2 \text { years } \\
2.0-3.9 \text { years } \\
4.0-4.9 \text { years }\end{array}$ & $\begin{array}{l}127(38) \\
142(42) \\
68(20)\end{array}$ & $\begin{array}{l}25(20) \\
17(12) \\
9(13)\end{array}$ & $\begin{array}{l}102(80) \\
125(88) \\
59(87)\end{array}$ \\
\hline $\begin{array}{l}\text { Sex } \\
\text { Male } \\
\text { Female }\end{array}$ & $\begin{array}{l}175(52) \\
162(48)\end{array}$ & $\begin{array}{l}21(12) \\
30(19)\end{array}$ & $\begin{array}{l}154(88) \\
132(81)\end{array}$ \\
\hline $\begin{array}{l}\text { Region } \\
\text { Kisumu urban } \\
\text { Kisumu rural }\end{array}$ & $\begin{array}{l}230(68) \\
107(32)\end{array}$ & $\begin{array}{l}28(12) \\
23(22)\end{array}$ & $\begin{array}{l}202(88) \\
84(78)\end{array}$ \\
\hline $\begin{array}{l}\text { Relationship to index case } \\
\text { First degree relative (FDR) } \\
\text { Second Degree relation and non-relative }\end{array}$ & $\begin{array}{l}222(66) \\
115(34)\end{array}$ & $\begin{array}{l}41(19) \\
10(9)\end{array}$ & $\begin{array}{l}181(91) \\
105(91)\end{array}$ \\
\hline $\begin{array}{l}\text { Duration lived with index case } \\
\quad<90 \text { days } \\
\quad \geq 90 \text { days }\end{array}$ & $\begin{array}{l}107(32) \\
230(68)\end{array}$ & $\begin{array}{l}14(13) \\
37(16)\end{array}$ & $\begin{array}{c}93(87) \\
193(84)\end{array}$ \\
\hline $\begin{array}{l}\text { Contact number of hours per day } \\
\quad<8 \text { hours } \\
8-24 \text { hours }\end{array}$ & $\begin{array}{l}104(31) \\
233(69)\end{array}$ & $\begin{array}{l}14(13) \\
37(16)\end{array}$ & $\begin{array}{c}90(87) \\
196(84)\end{array}$ \\
\hline $\begin{array}{l}\text { Shared a bedroom with index case } \\
\text { Yes } \\
\text { No }\end{array}$ & $\begin{array}{l}206(61) \\
131(39)\end{array}$ & $\begin{array}{l}31(15) \\
20(15)\end{array}$ & $\begin{array}{l}111(85) \\
175(85)\end{array}$ \\
\hline $\begin{array}{l}\text { BCG } \\
\text { Given scar present } \\
\text { Given scar absent } \\
\text { Not given }\end{array}$ & $\begin{array}{c}301(90) \\
28(8) \\
8(2)\end{array}$ & $\begin{array}{l}42(14) \\
8(29) \\
1(13)\end{array}$ & $\begin{array}{l}259(86) \\
20(72) \\
7(87)\end{array}$ \\
\hline $\begin{array}{l}\text { Ever received IPT } \\
\text { Yes } \\
\text { No }\end{array}$ & $\begin{array}{c}16(5) \\
321(95)\end{array}$ & $\begin{array}{c}6(38) \\
45(14)\end{array}$ & $\begin{array}{c}10(62) \\
276(86)\end{array}$ \\
\hline $\begin{array}{l}\text { Ever had TB } \\
\text { Yes } \\
\text { No }\end{array}$ & $\begin{array}{c}3(1) \\
337(99)\end{array}$ & $\begin{array}{c}0(0) \\
51(15)\end{array}$ & $\begin{array}{c}3(100) \\
283(85)\end{array}$ \\
\hline $\begin{array}{l}\text { HIV status*** } \\
\text { Positive } \\
\text { Negative }\end{array}$ & $\begin{array}{c}13(4) \\
281(96)\end{array}$ & $\begin{array}{l}2(15) \\
41(15)\end{array}$ & $\begin{array}{c}11(85) \\
240(85)\end{array}$ \\
\hline $\begin{array}{l}\text { TB Symptoms } \\
\text { Present } \\
\text { Absent }\end{array}$ & $\begin{array}{c}91(27) \\
246(73)\end{array}$ & $\begin{array}{l}11(12) \\
40(16)\end{array}$ & $\begin{array}{c}80(88) \\
206(84)\end{array}$ \\
\hline
\end{tabular}

*FDR includes siblings ( $\mathrm{n}=25)$ and parents $(\mathrm{n}=202)$, Second degree relatives includes grandparents, grandchild, uncles, aunts, nieces, nephews and cousins; and 13 persons who are not related to the index case ***HIV test results not documented for 45 contacts. 
rature, where the index case was not a parent, attendance at IPT clinics was a lot less. ${ }^{19}$

Published literature indicates that health seeking behavior by parents is better for male children compared to that for female children $^{20}$ and varies inversely with. ${ }^{21}$ Although we observed a higher proportion of female children initiated on IPT, this was not achieved statistical significance. ${ }^{22}$

Because we had to rely on programmatic data, difficulties were experienced in matching the research study database to those in the TB program registers. Therefore, the matching may have been incomplete. Additionally, IPT initiation within the TB program had just been launched; the program personnel had just com- menced on completing the IPT registers and therefore may have not entered all the names of persons on IPT in the registers. Furthermore, there were drug stock outs that may have led to sub optimal IPT initiation and completion rates.

\section{Conclusions}

Although Household Contact investigation in Kisumu county forms a good entry point for identifying child contacts in need of Tuberculosis Chemoprophylaxis, IPT initiation rates are suboptimal. The TB program should therefore train health workers on the importance of TB chemoprophylaxis and dispel their fears about Isoniazid toxi- city and risks of resistance, avail TB diagnostic tools that can reliably exclude a TB diagnosis prior to IPT initiation and ensure continuous and steady supply of IPT to ensure optimal IPT uptake and completion rates. The TB program should also provide job aids and linked TB and IPT registers to facilitate the management of TB indexchild contact pairs and programmatic monitoring. Health education should be directed to ensure TB patients and their families, and the general population, understand the increased risk of contracting TB among children, the increased risk of TB progression once infected, and the importance of IPT prophylaxis. Targeted interventions should be formulated to reach those who are unlikely to initiate IPT.

Table 5. Multivariate logistic regression illustrating Characteristics household contacts aged less than 5 years of Index cases of tuberculosis (TB) at Kisumu County, 2014-2015 by Isoniazid Preventative Therapy (IPT) initiation status.

\begin{tabular}{|c|c|c|c|c|c|}
\hline Characteristics & $\begin{array}{l}\text { IPT/Total IPT } \\
\text { eligible 51/337 } \\
\text { (15\%); n/N (\%) }\end{array}$ & $\begin{array}{l}\text { Crude Odds Ratio } \\
\qquad(95 \% \mathrm{CI})\end{array}$ & P value & $\begin{array}{l}\text { Adjusted Odds Ratio } \\
\text { (95\% CI) }\end{array}$ & P value \\
\hline $\begin{array}{l}\text { Age group } \\
\quad<2 \text { year } \\
\quad 2.0-3.9 \text { years } \\
4.0-4.9 \text { years }\end{array}$ & $\begin{array}{l}25 / 127(20) \\
17 / 142(12) \\
9 / 68(13)\end{array}$ & $\begin{array}{l}1.6(0.7-3.7) \\
0.9(0.4-2.1) \\
\quad \text { Ref }\end{array}$ & $0.18 *$ & & \\
\hline $\begin{array}{l}\text { Sex } \\
\quad \text { Male } \\
\text { Female } \\
\end{array}$ & $\begin{array}{l}21 / 175(12) \\
30 / 162(19)\end{array}$ & $\begin{array}{c}\text { Ref } \\
1.7(1.0-3.1)\end{array}$ & $0.09 *$ & $\begin{array}{c}\text { Ref } \\
1.9(1.0-3.6) \\
\end{array}$ & 0.05 \\
\hline $\begin{array}{l}\text { Region } \\
\text { Kisumu Urban } \\
\text { Kiusmu Rural }\end{array}$ & $\begin{array}{l}28 / 230(12) \\
23 / 107(22)\end{array}$ & $\begin{array}{c}\text { Ref } \\
1.9(1.1-3.6)\end{array}$ & $0.02^{*}$ & $\begin{array}{c}\text { Ref } \\
2.6(1.4-5.1)\end{array}$ & $<0.01$ \\
\hline $\begin{array}{l}\text { Relationship to index case* } \\
\text { Parent, sibling or grandparent } \\
\text { Other relation/non relative }\end{array}$ & $\begin{array}{l}41 / 222(19) \\
10 / 115(9)\end{array}$ & $\begin{array}{c}2.4(1.1-4.9) \\
\text { Ref }\end{array}$ & $0.01^{*}$ & $\begin{array}{c}2.6(1.2-5.5) \\
\operatorname{Ref}\end{array}$ & 0.02 \\
\hline $\begin{array}{l}\text { Duration lived with index case } \\
<90 \text { days } \\
90+\text { days }\end{array}$ & $\begin{array}{l}14 / 107(13) \\
37 / 230(16)\end{array}$ & $\begin{array}{c}\text { Ref } \\
1.2(0.6-2.4)\end{array}$ & 0.5 & & \\
\hline $\begin{array}{l}\text { Contact No. of hours per day } \\
<8 \text { hours } \\
\text { 8-24 hours }\end{array}$ & $\begin{array}{l}14 / 104(13) \\
37 / 233(16)\end{array}$ & $\begin{array}{c}\text { Ref } \\
1.2(0.6-2.4)\end{array}$ & 0.6 & & \\
\hline $\begin{array}{l}\text { Shared bedroom with index case } \\
\text { Yes } \\
\text { No }\end{array}$ & $\begin{array}{l}31 / 206(15) \\
20 / 131(15)\end{array}$ & $\begin{array}{l}1.1(0.6-1.9) \\
\quad \operatorname{Ref}\end{array}$ & 0.9 & & \\
\hline $\begin{array}{l}\text { BCG } \\
\text { Given scar present } \\
\text { Given scar absent } \\
\text { Not given }\end{array}$ & $\begin{array}{c}42 / 301(14) \\
8 / 28(29) \\
1 / 8(13)\end{array}$ & $\begin{array}{c}\text { Ref } \\
2.5(1.0-5.9) \\
0.9(0.1-7.3)\end{array}$ & $0.1^{*}$ & $\begin{array}{c}\text { Ref } \\
2.9(1.2-7.5) \\
1.1(0.1-10.3)\end{array}$ & 0.07 \\
\hline $\begin{array}{l}\text { Ever received IPT } \\
\text { Yes } \\
\text { No }\end{array}$ & $\begin{array}{c}6 / 16(38) \\
45 / 321(14)\end{array}$ & $\begin{array}{l}3.7(1.3-10.6) \\
\quad \text { Ref }\end{array}$ & $0.01^{*}$ & $\begin{array}{l}2.9(0.9-8.7) \\
\quad \text { Ref }\end{array}$ & 0.06 \\
\hline $\begin{array}{l}\text { HIV status** } \\
\text { Positive } \\
\text { Negative }\end{array}$ & $\begin{array}{c}2 / 13(15) \\
41 / 281(15)\end{array}$ & $\begin{array}{c}\text { Ref } \\
1.1(0.2-4.9)\end{array}$ & 0.9 & & \\
\hline $\begin{array}{l}\text { TB Symptoms } \\
\text { Present } \\
\text { Absent }\end{array}$ & $\begin{array}{c}11 / 91(12) \\
40 / 246(16)\end{array}$ & $\begin{array}{c}\text { Ref } \\
1.4(0.7-2.9) \\
\end{array}$ & 0.3 & & \\
\hline
\end{tabular}

*Entered into the multivariate logistic model,**Missing data for 43 contacts. History of prior TB treatment excluded due to no participants with prior TB being initiated on IPT. 


\section{References}

1. Erkens CGM, Kamphorst M, Abubakar I, et al. Tuberculosis in low prevalence countries: A European consensus Eur Respir J 2010;36:925-49.

2. Nderoli TE, Carpenter CCJ, Plum F, Smith Jr LHS, eds. Cecil Essentials of Medicine. 2nd ed. USA: W.B. Saunders Company; 1990.

3. Anger HA, Proops D, Haaris TG, et al. Active Case finding and prevention of tb among a cohort of contact exposed to infectious TB cases in New York City. Clin Infect Dis 2012;54:1287-95.

4. Herchline TE, Amorosa JK. Tuberculosis. 2012. Available from: http://emedicine.medscape.com/article/230802-overview

5. Haslett C, Chilvers ER, Hunter JAA, Boon NA, eds. Davidson's Principles and practices of Medicine 18th ed. Toronto: Harcourt Publishers; 1999.

6. Division of Leprosy Tuberculosis and Lung Disease DTLD Kenya. National pediatric TB care guidelines. DLTLD; 2012.

7. Banu Rekha VV, Jagarajamma K, Wares F, et al. Contact screening and chemoprophylaxis in India's Revised Tuberculosis Control Programme: a situational analysis. Int J Tuberc Lung Dis 2009;13:1507-12.

8. MacIntyre CR, Plant AJ. Impact of Policy and Practice on the Effectiveness of Contact Screening for Tuberculosis.
Prev Med 2010;27:830-7.

9. Mars Group. Kisumu East District. 2013. Available from: http://www.marsgroupkenya.org/census/?data=phoudr\&province $=7:$ Nyanza + Province $\&$ dist rict=604:KISUMU+EAST+District

10. Division of Leprosy Tuberculosis and Lung Diseases D, Kenya. Annual Report 2014. Nairobi, Division of Leprosy Tuberculosis and Lung Diseases; 2015.

11. Bruce N, Pope D, Stanistreet D. Quantitative Research Methods in Public Health; A practical, interactive guide. England: J Wiley \& sons.; 2007.

12. SAS Institute Inc, inventor SAS/STAT (R 9.2 User's Guide. Cary, NC. 2012.

13. World Health Organization. Recommendations for investigating contacts of persons with Infectious Tuberculosis in Low and Middle income countries. 2012. Available from: http://www.who.int/tb/publications/201 2/contact investigation2012/en/

14. Pothukuchi M, Nagaraja SB, Kelamane $\mathrm{S}$, et al. Tuberculosis Contact Screening and Isoniazid Preventive Therapy in a South Indian District: Operational Issues for Programmatic Consideration. Plos One 2011;6:e22500.

15. Tadesse Y, Gebre N, Daba D, et al. Uptake of Isoniazid Preventive Therapy among Under-Five Children: TB Contact Investigation as an Entry Point. PLoS One 2016;11:e0155525.

16. Shivaramakrishna HR, Frederick A,
Shazia A, et al. Isoniazid preventive treatment in children in two districts of South India: does practice follow policy? Int $J$ Tuberc Lung Dis 2014;18:912-24.

17. Hughes RG, ed. Patient Safety and Quality: An Evidence-Based Handbook for Nurses. Rockville, MD: AHRQ Publication; 2008.

18. Sadaphal S, Kak N, Holschneider S, et al. Quality Improvement Handbook for TB and MDR-TB Programs: University Research CO., LLC Funded by United States Agency for international Development; 2013.

19. Hall C, Sukijthamapan P, dos Santos R, et al. Challenges to delivery of isoniazid preventive therapy in a cohort of children exposed to tuberculosis in TimorLeste. Trop Med Int Health 2015;20:730-6.

20. Taffa N, Chepngeno G. Determinants of health care seeking for childhood illnesses in Nairobi slums. 2005;10:240-245. Trop Med Int Heal 2005;10:240-5.

21. Sarker AR, Sultana M, Mahumud RA, et al. Prevalence and Health CareSeeking Behavior for Childhood Diarrheal Disease in Bangladesh. Glob Pediatr Health 2016;3.

22. Birk NM, Nissen TN, Ladekarl M, et al. The association between Bacillus Calmette-Guérin vaccination (1331 SSI) skin reaction and subsequent scar development in infants. BMC Infect Dis $2017 ; 17$. 